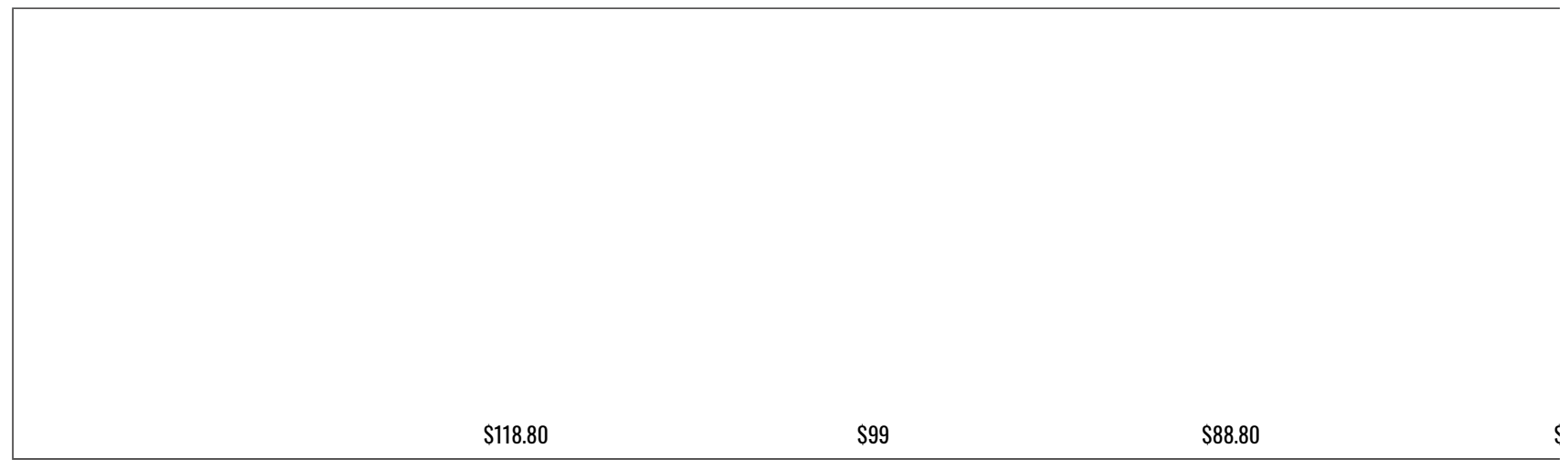

$r$

\title{
The Most Important Question for Trump Judicial Nominees
}

JURISPRUDENCE

How much executive authority do they think the president has?

By PETER M. SHANE

JULY 05, 2017 - 1:37 PM

7WEET

f SHARE

COMMENT

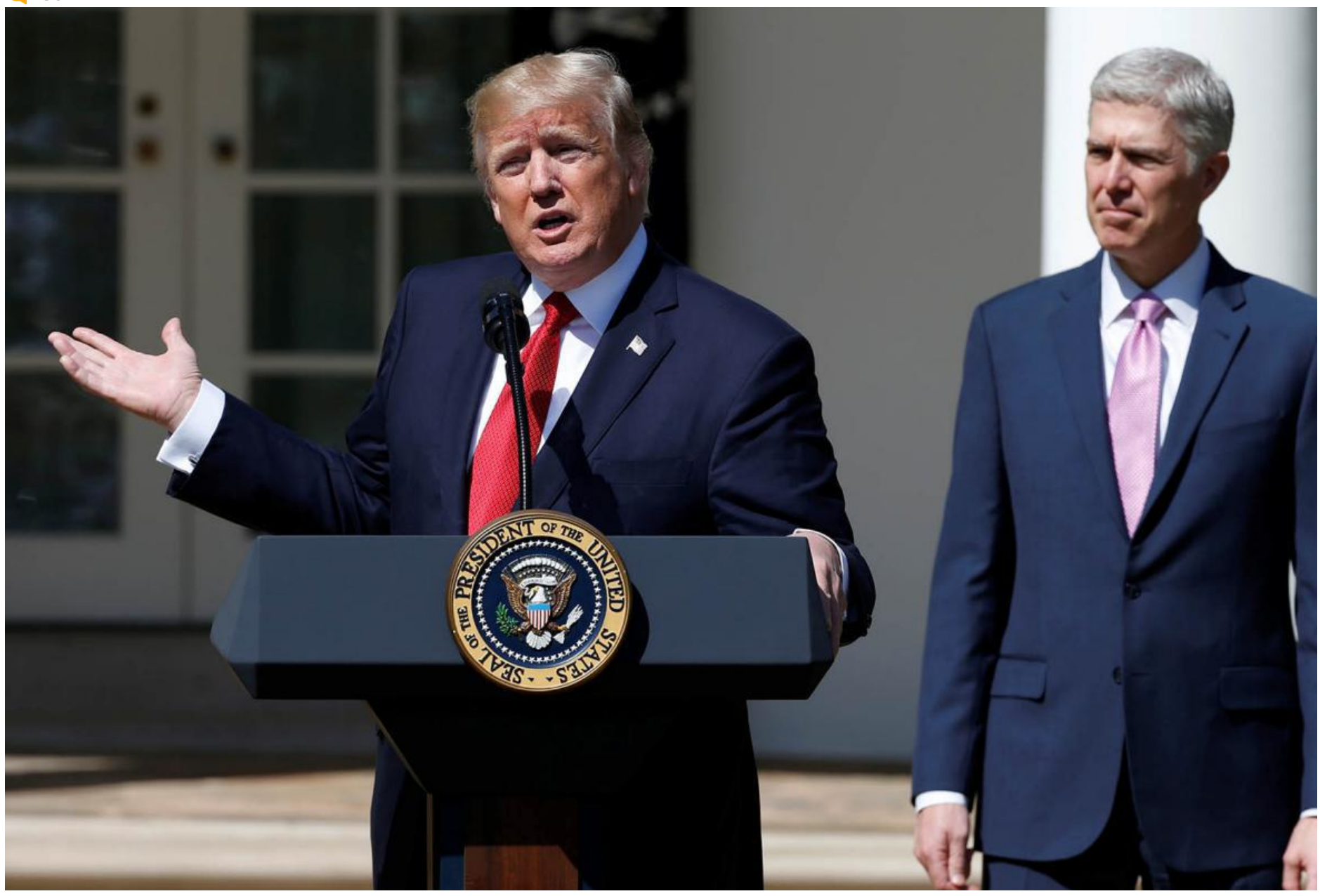


Donald Trump speaks before the swearing in of Judge Neil Gorsuch as a Supreme Court justice in the Rose Garden of the White House in Washington on April 10.

Joshua Roberts/Reuters

It wasn't that long ago that "litmus test" was a dirty phrase in judicial nominations. In the late 1970s, I clerked for a distinguished Jimmy Carter appointee to the U.S. Court of Appeals for the $5^{\text {th }}$ Circuit. My judge was troubled that, en route to his nomination, he had been asked by the Carter administration for his general views on affirmative action-views that, as it happened, were entirely in accord with the president's. He believed, however, if an outstanding lawyer had been a loyal member of the president's party, it was inappropriate to impose any more fine-grained test of a potential judge's ideological compatibility.

Decades later, the discrete litmus tests each party imposes on judicial nominees-and particularly those imposed by the Federalist Society-enamored Republican Party-have evolved into a nearly procrustean template. No clearer evidence could be imagined than Donald Trump's outsourcing the selection of federal appellate judges, including Supreme Court Justice Neil A. Gorsuch, to the Federalist Society. And at the current moment, no aspect of Federalist Society orthodoxy should be more troubling than its members' frequent genuflection to presidential power. Going forward, it is imperative that no judicial candidate nominated by President Donald J. Trump be confirmed by the Senate without a far more thorough and well-informed interrogation of their views of executive power than we have witnessed so far.

Since the 1980s, the Federalist Society and its judicial fellow travelers have become unabashed champions of something called "unitary executive theory." Under this doctrine, the Constitution supposedly guarantees the president complete command-and-control authority over how every member of the executive branch exercises whatever legal authority Congress has vested in them. Moreover, Federalist Society lawyers are inventive at divining broad presidential powers in the Constitution; the current "emoluments" fight shows this creativity in the effort to fend off constitutional restraints on self-dealing.

It would be a mistake to treat Federalist constitutional theorizing dismissively, even if it crops up most conspicuously when the White House is occupied by a Republican and can feel politically motivated. Although squaring their professed allegiance to constitutional "originalism" with their view of the presidency requires some cherry-picking of the relevant evidence, there is at least some evidence to cherry-pick. The scholars among the "unitary executive" backers are serious, often thoughtful people, and "motivated reasoning" is not a challenge confined to their end of the political spectrum. 
In the same spirit, it should be acknowledged that some of the president's nominees are the kinds of accomplished, deeply conservative lawyers one would expect any contemporary Republican president to nominate. Yet their enthusiasm for unchecked executive power should be profoundly worrying. For example, Michigan Supreme Court Justice Joan Larsen, a nominee to the $6^{\text {th }}$ Circuit, wrote approvingly of a President George W. Bush "signing statement" in which Bush indicated he was not necessarily bound by the anti-torture provisions of a 2005 emergency appropriations act. Justice Larson opined: "Denying the president a constitutional voice is the real threat to our system of separated powers." She went on to say: "If circumstances arose in which the law would prevent him from protecting the nation, he would choose the nation over the statute." She wrote this not as President Bush's lawyer but as a law professor. We cannot afford judges who would grant President Trump extreme leeway to decide what statutes he may ignore in the interest of what so mercurial and unreliable a leader might deem "protecting the nation."

To be sure, there are also some nominees who should be deemed utterly disqualified for lack of judicial temperament and explicit hostility to constitutional rights. Damien M. Schiff, a senior attorney at the Pacific Legal Foundation and nominee for the U.S. Court of Federal Claims, has called Justice Anthony Kennedy "a judicial prostitute." Writing under the pseudonym G. Morris, attorney John K. Bush, a nominee to the U.S. Court of Appeals for the $6^{\text {th }}$ Circuit, has written inflammatory and demeaning anti-LGBTQ blog posts for an ultraconservative website run by his wife. The unsuitability of such nominees, however, reveals itself in plain sight. Too ready an acceptance of presidentialism-uncritically interpreting the Constitution as giving presidents a fixed and expansive set of authorities largely immune to legislative control or judicial review-is a subtler, but no less dangerous fault.

Ideally, members of the Senate Judiciary Committee will have the knowledge, determination, and questioning skill to grill Trump's nominees thoroughly on their attitudes toward presidential authority. Eliciting platitudes like no one is above the law is of no use; we need to know how a prospective judge would go about discerning what the law is and how she feels about presidential power. Given the Trump administration's seeming contempt for long-standing norms of transparency and accountability, these confirmation hearings should become a national seminar of sorts on law and the presidency. 
If a judge professes to be an originalist like Justice Antonin Scalia, she should be asked how unitary executive theory can be squared with originalism. If the response is something like, "The Constitution vests executive power in the president," the riposte should be, "What precisely does that mean to you and what specific history are you basing that on?" Various Federalist Society scholars insist it means the president can take over an entire administration himself and remove anyone in the executive branch at will. But early attorneys general disagreed. They concluded presidents could not simply take over tasks that Congress had assigned specifically to other administrative officers. How open would the nominee be to evidence that the founding generation expected Congress would have significant authority to constrain presidential action?

We should know whether nominees think independent agencies-or for that matter, the whole civil service-should be regarded as unconstitutional because presidents cannot fire everyone at will. They should tell us if presidents may invoke executive privilege against Congress and, if so, whether anyone other than the president may invoke privilege on his behalf. Acknowledging that the executive branch gets significant deference from judges when it acts in good faith, we should know what prospective judges think would be probative evidence of bad faith. For example, how deferential would a nominee be to presidential action justified one way in a government brief but very differently in the president's repeated public statements?

Senators on both sides of the aisle should not behave as if anything goes. Republican senators, no less than Democratic senators, have sworn to uphold the Constitution, including a proper understanding of how both Congress and the courts can hold presidents accountable to the rule of law. Progressives need to accept that a Republican administration means that we are going to have more conservative Republican judges. Conservatives should understand that doesn't mean we need to populate the judiciary with rhetorical bomb-throwers or ideologues in thrall to executive power.

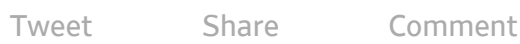

Donald Trump Supreme Court

Forget Skinny Jeans. These Are What You Should Be Wearing This Winter.

American Giant |Sponsored

'Americas Favorite Veterinarian' Reveals The One Thing Every Dog Owner Should Do

Ultimate Pet Nutrition | Sponsored

Don't Miss Seeing These New \& Redesigned 2019 Vehicles

Kelley Blue Book |Sponsored

How Can You Outsmart Amazon? Turns Out It's Pretty Simple 